\title{
THE ISLE OF PINES: AN IMPERFECT UTOPIA
}

\author{
Adelaide Meira Serras \\ Universidade de Lisboa
}

\begin{abstract}
Henry Neville's The Isle of Pines (1668) is an early and popular example of fictional travelwriting. It describes the unorthodox way of living of an insular society founded by a few survivors of a shipwreck. Although in a light tone, Neville raises sensitive topics: the then current gender ideology, racism, common property, and the violent conducts of European settlers. He also ponders the role of religious doctrine in the moulding of individuals. So, measuring what Neville conveys in a positive or negative light could classify this fiction as eutopia or dystopia. It is undoubtedly the depiction of a community of imperfect mortals, an imperfect utopia, thereby contradicting the genre's prime definition as the recipe for a planned -ergo, happy- society.
\end{abstract}

KEYWORDS: utopia/dystopia, seventeenth-century seafaring, gender ideology, racism.

\section{LA ISLA DE LOS PINOS: UNA UTOPÍA IMPERFECTA}

\section{RESUMEN}

The Isle of Pines (1668. La isla de los Pinos), de Henry Neville, es un ejemplo temprano y popular de literatura de viajes en ficción. La obra describe el estilo de vida nada ortodoxo de una sociedad insular fundada por unos pocos supervivientes de un naufragio. Aunque en un tono desenfadado, Neville plantea asuntos muy delicados: la ideología de género predominante en la época, el racismo, la propiedad colectiva, y las conductas violentas de los colonos europeos. Él también reflexiona sobre el papel de la doctrina religiosa en la formación de los individuos. De este modo, evaluar lo que Neville presenta de manera positiva o negativa permitiría clasificar este relato como eutopía o distopía. Indudablemente se trata de mostrar una comunidad de mortales imperfectos, una utopía imperfecta, y en consecuencia entra en contradicción con la definición primordial del género como la fórmula para una sociedad planificada -y por lo tanto feliz.

Palabras Clave: utopía/distopía, viajes marítimos del siglo XviI, ideología de género, racismo.

DOI: https://doi.org/10.25145/j.recaesin.2019.79.05

Revista Canaria de Estudios Ingleses, 79; November 2019, pp. 71-87; ISSN: e-2530-8335 
Henry Neville's The Isle of Pines Or, A late Discovery of a fourth ISLAND in Terra Australis, Incognita went to press in 1668 and was published almost simultaneously in different versions -Dutch, German, French and English-raising some doubts about its authorship and authenticity, though proving its popularity. Readers who believed in the geographical and navigational data it conveyed saw it as a tract; for those who mistrusted its content it was considered a hoax. Its full title was:

The Isle of Pines. Or, A late Discovery of a fourth ISLAND near Terra Australia, Incognita. By Henry Cornelius Van Sloetten. Wherein is contained. A true Relation of certain English persons, who in Queen Elizabeths time, making a Voyage to the East Indies, were cast away, and wracked near to the Coast of Terra Australis, Incognita, and all drowned, except one Man and four Women. And now lately Anno Dom. 1667. a Dutch Ship making a Voyage to the East Indies, driven by foul weather there by chance have found their Posterity (speaking good English) to amount (as they suppose) to ten or twelve thousand persons. The whole Relation (written and left by the Man himself a little before his death, and delivered to the Dutch by his Grandchild) Is here annexed with the Longitude and the Latitude of the Island, the situation and felicity thereof, with other matter observable. (Neville 62)

Apart from the hazardous editorial record, ${ }^{1}$ due to the complexity of censorship and print licensing during the Restoration this text constitutes a curious example of utopian writing, a popular genre in the seventeenth century. At first glance, it seems to present a rather ordinary proposal of an Edenic society founded on an Australian island by a few survivors of a shipwrecked East India Merchant Company vessel that had sailed for the East Indies during the reign of Elizabeth I.

The date of its publication -1668- corresponds to the first years of the Restoration period when the sense of relief from the claustrophobic atmosphere of English society during the Cromwellian period and the transition to Charles II's merrier way of living triggered a sense of euphoria: the reopening of theatres and fairs, the sponsoring of the new sciences epitomised by the Royal Society and its leading figures like Isaac Newton or Pierre Boyle among many others, or the surge of baroque music (with the works of composers like Henry Purcell), all pointed to a richer and more enjoyable era. Even the Great Fire of 1666, though a tremendous disaster, brought about the hope of urban renewal in the form of a more elegant, better planned London made possible through the creative genius of architect Christopher Wren. A restored regime together with a rebuilt city worked as metaphors for a new notion of political belonging: instead of the unequal relationship between royalty and subject, an egalitarian bond among members of society seemed plausible, almost probable. Everything was possible and new models of society could be experienced.

${ }^{1}$ For information on this utopia's editions consult Worthington Chauncey Ford, The Isle of Pines by Henry Neville, 1688. An Essay in Bibliography, or the more recent critical edition by John Scheckter, The Isle of Pines, 1668: Henry Neville's Uncertain Utopia. 
The parallel between the reigns of Elizabeth I and Charles II stands clearly as the outcome of two major national crises, bearing in mind that etymologically crisis

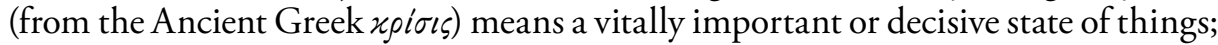
a point at which change must come, for better or worse. The hope and prosperity during the reign of Elizabeth I and the rebirth of the monarchy with Charles II both seemed to promise social stability by means of the "artificial eternity" of this political model, as Hobbes names it in his Leviathan (101). However, at the same time, these reigns promised relevant changes in governmental, social and religious issues. The main difference between these two moments is that the former belonged to the past, to English history, whereas the latter was still a promise open to be shaped by intervenients, either by institutional entities, such as parliament and government, or by the emergent public opinion disseminated in newspapers, in coffee and chocolate houses, and clubs, or, in a more individualistic way, in utopian writing.

According to Nichole Pohl, "utopia is inseparable from the imaginary voyage," but usually it is a plausible voyage within the contemporaneous reader's view of the known world (53). The choice of going on a voyage to Australia by an employee of the English East India Merchant Company meets the premise of reliability of the following narrative. The Company was part and parcel of the English maritime enterprise which had gained momentum during the reign of Elizabeth I with Sir Walter Raleigh's attempt to establish an English colony on Roanoke Island. There was also an increase in commercial routes across the Atlantic and the Pacific following the Portuguese and Spanish Discoveries. As the narrator acknowledges:

A Way to the East India's being lately discovered by Sea, to the $\{\{7\}\}$ South of Affrich by certain Portugals, far more safe and profitable then had been before; certain English Merchants encouraged by the great advantages arising from the Eastern Commodities, to settle a Factory there for the advantage of Trade. And having to that purpose obtained the Queen's Royal Licence Anno Dom. 1569. 11. or 12. (Neville 65)

The history of the rise of the English -and later British- Empire registers many challenges that both rulers and merchants had to overcome. In the political arena, England was fighting the international divide of newly-found territories between Spain and Portugal registered in a Papal bull issued by Pope Alexander VI in 1494. During the first half of the seventeenth century, a long debate was underway regarding the ownership of maritime space which sowed the first premises of international law with the significant contribution of Hugo Grotius' Mare Liberum, 1608. As David Armitage points out, England was simultaneously competing with Scottish maritime expansionism, a rivalry which weakened each other's standing: "The history of British maritime ideology in the sixteenth and seventeenth centuries follows the history of the conception of Britain itself. There could obviously not be any pan-British arguments in favour of maritime supremacy until the state itself had been defined as a collectively British kingdom" (Armitage 102).

Therefore, the English East India Merchant Company was meant to play a fundamental role in the Elizabethan expansionist ideology. Moreover, it was an example of the recently implemented economic system, mercantilism, or the 
"mercantile system," an expression coined by Adam Smith in his Wealth of Nations. Briefly, it consisted of an economic nationalist practice and a theory which, for the first time, defined the wealth of a country by its good balance of trade, or rather, by its restraining of imports and encouraging of exports in order to accumulate precious metals -i.e. bullions- in the state coffers (Laura LaHaye 2008). ${ }^{2}$ English mercantilism emphasised trade and had a rather pragmatic bias when compared with the more conceptual approach of French thinkers such as Montchrétien or JeanBaptiste Colbert. Thomas Mun, one of the first apologists for mercantilism and a member of the said Company, wrote a pamphlet, $A$ Discourse of Trade, from England unto the East Indies (1621), where he argued that as long as England's total exports exceeded its total imports in the process of visible trade, the export of bullion was not harmful. His most famous work, England's Treasure by Foreign Trade, published posthumously in 1664, was labeled the "handbook of mercantilism" by Adam Smith. This new practice also implied strong regulation on the part of the government by means of issuing charters -that is, licenses to trade or manufacture certain items or to exploit certain maritime routes- which constituted a new source of revenue and controlled competition. The creation of monopolies was a key measure defended in Brief Observations Concerning Trade and the Interest of Money (1668) and A New Discourse of Trade $(1668,1690)$ by Josiah Child, a most prominent mercantilism apologist of the times, though also a stockholder of the Company and later its governor, circumstances which raise questions as to his impartiality.

The East India Company is a good example of the creation of chartered monopolies. It was founded in 1600 as a joint-stock company, and after disputing the monopoly of their chosen routes with the Dutch and the Portuguese, the Company focused on trading cotton, silk, indigo, saltpeter, and spices from South India, and quickly extended its activities to the Persian Gulf, Southeast Asia, and East Asia. Later, the slave trade became a lucrative enterprise. This activity directly attacked human dignity and, more accurately, non-European human freedom and dignity. This trade fed emergent racist attitudes that went hand-in-hand with economic and political ambitions, attitudes that were soon justified by pseudo-scientific theories presented, for instance, by François Bernier's Nouvelle Division de la Terre par les Différentes Espèces ou Races qui l'habitent [New Division of the Earth by the Different Species or Races that inhabit it] (1684), or later by the slave owner Edward Long whose History of Jamaica (1774) became quite popular. Both works characterised the different races according to physical features, such as colour, skull dimension or type of hair, and from there inferred several intellectual and ethical derogatory traits of the so-called African race considering them inferior beings incapable of civilisation.

In mercantilism, despite its darker moral or material aspects, trade and seafaring found common political and economic grounds: territorial expansionism

\footnotetext{
${ }^{2}$ For information on mercantilism consult John J. Cusker and Kenneth Morgan, eds., The Early Modern Atlantic Economy (Cambridge UP, 2001).
} 
intertwined with the territorial ownership of the European powers involved in the maritime enterprise. This led to the hegemonic position of England in the international chess game of European states. For the common man, it paved the way to the quick acquisition of wealth and consequent upward mobility. Samuel Purchas, in Hakluytus Posthumus or Purchas his Pilgrimes; Contayning a History of the World, in Sea Voyages and Lande Travells, by Englishmen and Others (1625), praised the new economic dynamics of the sea:

It is the great Purveyor of the Worlds Commodities to our use, Conveyor of the Excesse of Rivers, Uniter by Traffique of al Nations [...] it is an open field for Merchandize in Peace [...] refuge to the distressed, Portage to the Merchant, passage to the Traveller, Customes to the Prince [...]. (Purchas 62)

Turbulent voyages, bad winds, tempests and the loss of bearings followed by shipwreck were recurring phenomena among the men who earned their living crossing the oceans. This did not deter the many men who were willing to adventure upon these rough waters, or who aspired to move up the social ladder. Bernardo Gomes de Brito's several stories -collected in his História Trágico-Maritima-prove the adventurous spirit of these travelers. Published in two volumes in 1735-1736, this Tragic History of the Sea is a collection of narratives, chronologically presented, of dangerous voyages and shipwrecks of Portuguese sailors on their Atlantic route to and from India -the spice route- between 1552 and 1602. In his autobiographical work Peregrinação [Pilgrimage] (posthumously published in 1614), Fernão Mendes Pinto reports the many dangers he faced on his travels to India, China, Japan and other Far Eastern countries: pirate attacks and subsequent periods of slavery, natural phenomena and shipwrecks. His account, albeit partially dubious, is considered a literary master-piece because of his educated assessment of other cultures and of the nature of the interaction between European navigators and the "Others," as Said (1978) names those belonging to other cultures, living on other continents, and, quite often, becoming colonised by the empowered newcomers. Fictional works, especially utopias, adopted the said device: Francis Bacon, for instance, in his New Atlantis, tells how a crew and their captain arrived at the island of Bensalem in the aftermath of a terrible tempest which diverted them from their original route; Jonathan Swift's hero in Gulliver's Travels (1726) is also a victim of shipwreck more than once in his voyages. So, Henry Neville adopted a well-tested device to introduce the reader to the plausible arrival of a small group of survivors on a beautiful, exotic island somewhere in the Pacific Ocean, close enough to already established longitudes and latitudes. Moreover, the immense cluster of Indonesian islands and its estimated proximity to the so-called Terra Australis made the location of the subsequent narrative credible enough for some readers to consider it as travel writing, a genre then much appreciated. Neville also uses another device to ensure the plausibility of the story: a report of the creation of the colony in the form of a letter written by George Pine, the founder of the community, is passed on almost a century later by one of his descendants to a Dutch traveler, Captain Cornelius Van Sloetten, who landed on the island. To reinforce its authenticity, Neville added two other letters 
signed by a Dutch merchant named Abraham Keek reporting that a French ship had discovered the island, though locating it in a slightly different place: "two or three hundred leagues 'Northwest from Cape Finis Terre" (Ford 56). Captain Van Sloetten even vouches for the credibility of the source: "This story seems fabulous, yet the Letter is come to a known Merchant, and from a good hand in France" (Neville 62).

This resorting to an autoritas to create a realistic narrative can also be found in More's Utopia with the exchange of letters between his authorial persona and Peter Giles (112-114), Peter Giles and Jerome Busleyden (124-29), or from William Bude to Thomas Lupset (115-121), although these letters keep an ironic ambiguity never fully asserting the veracity of the Republic of Utopia. The short poem entitled "Six Lines on the Island of Utopia, Written by Anemolius, Poet Laureate and Nephew to Hythloday by his Sister" (More 121) seemed to meet the goal of authenticity if the readers were willing to "suspend their disbelief," considering that Hythloday is but a fictional character - and a nonsensical one according to his name- and Anemolius is a Latinised version of the Greek "anemolios," meaning "windy"; so, the words of the poem go with the wind, i.e. they are not to be taken seriously. Henry Neville uses More's device but lacks More's rhetorical mastery of serio ludere, i.e. playing with serious matters, a literary model used by some Greek authors such as Lucian in True History and Apuleius in The Golden Ass, and adopted by Renaissance writers besides Thomas More, like Erasmus of Rotterdam with his Praise of Folly (1511) and, later, Swift. In Neville's case, the aim is simply to forge an atmosphere of reliability by means of two independent sources: a Dutchman and a French crew, two foreign entities with no ties to the English empire.

Ford, in his introductory text to Neville's work, attempted to compare it to Defoe's Robinson Crusoe (1719), stating that: "Life on an island, entirely separated from the rest of mankind, had formed an incident in many tales, but Neville's is believed to have been the first employment by an English author of island life for the whole story" (59). In fact, even though Neville borrowed the model of presenting his utopia from his predecessor, there are aspects which bring his creation close to Robinson Crusoe's proposition: life on an island isolated from the civilised world, as Ford highlighted, and the profiles of their respective protagonists. In both works, the prospective hero is an average man, someone belonging to the middling sort, that is, an individual of the bourgeoisie with some education, fairly young and keen to travel afar; someone with whom many eighteenth-century young men could easily identify. Of course, Robinson Crusoe is more adventurous and has a striking entrepreneurial energy which is absent in George Pine. Nonetheless, the latter is an accountant, a quite respectable and sought-after profession in times of trade with its inherent commercial and financial operations. They are both young and healthy and able to adapt to different circumstances through an experimental, empirical process when fate forces them to embrace a new way of living. They act as individuals, the new societies are of their own making; there is no collective ideal.

However, the similarities between Robinson Crusoe and George Pine seem to end here: Robinson undergoes a psychological and moral growth similar to the experience of bildungsroman heroes -an introspective, spiritual analysis-as 
well as an external adaptation to his surroundings using the knowledge and skills previously acquired, thus changing himself and the island he inhabits. George Pine, on the other hand, discards the moral and social notions he shared with his Christian, European fellowmen, and lets himself be absorbed by the environment. The new elements he introduces into his new locus are scarce, putting him and the other four survivors closer to the way of living of other species than to that of polite society. George Pine lacks Robinson Crusoe's teleological drive, a commitment to social transformation, an essential utopian feature of Bloch's definition of concrete utopia as literary texts of educated hope and in relation to the Real-Possible based on current tendencies and credible possibilities. In his conciliatory approach between Marxism and utopian literature, he distinguishes between abstract and concrete utopia: the former is a non-committed day-dream, whereas the latter anticipates and effects the future: "The thus determined imagination of the utopian function is distinguished from mere fantasizing precisely by the fact that only the former has in its favour a Not-Yet-Being of an expectable kind, i.e., does not play around and get lost in an Empty-Possible, but psychologically anticipates a Real Possible" (Bloch 1: 44). Or, as Levitas explains, "For Bloch, the unfinished nature of reality locates concrete utopia as a possible future within the real; and while it may be anticipated as a subjective experience, it also has objective status" (104). George Pine's circumstances of survival, however, highlight the apparent lack of purpose of this whole adventure:

we about the break of day discerned Land (but what we knew not) the Land seemed high and Rockey, and the Sea continued still very stormy and tempestuous, insomuch as there seemed no hope of safety, but looked suddenly to perish. As we grew near Land, perceiving no safety in the ship, which we looked would suddenly be beat in pieces: The Captain, my Master, and some others got into the long Boat, thinking by that means to save their lives, and presently after all the Seamen cast themselves overboard, thinking to save their lives by swimming, onely myself my Masters Daughters, the two Maids, and the Negro were left on board, for we could not swim; (Neville 65)

The situation is reported as every man for himself: the complete lack of chivalry in either the Captain's or the Master's behaviour towards the women -and especially the latter's indifference towards his wife and daughters- and the selfishness of the sailors all fit the depiction of a rough, dangerous life with no room for the Christian love of one's neighbour, the Greek notion of altruism, or, least of all, for affection. The darkest aspects of pragmatism and ambition are evident. Faced with danger, fear and self-preservation take the lead, as Hobbes repeatedly highlighted both in De Cive (1647) in the Dedication to William, Earl of Devonshire: "Man to Man is an arrant Wolfe"; and later in Leviathan (1651): "if there be no Power erected; or not great enough for our security; every man will, and may lawfully rely on his own strength and art, for caution against all other men" (Hobbes 87). Ironically, George Pine and the four women survived because of what they could not do; it was their dearth of abilities to conquer the adverse environment that protected them, which perhaps is a hint at what would be expected from them. 
An essential characteristic of utopia consists of the identification of the imagined society with the idea of "good place," although Vieira considers it a "notion to be discarded since it is based on a subjective conception of what is or not desirable, and envisages utopia as being essentially in opposition to the prevailing ideology" (6), a point The Isle of Pines clearly illustrates. The island where George Pine and the women found harbour revealed itself as a kind of paradise, perhaps an epicurean paradise, but undoubtedly one of the best places to survive with neither much in the way of human help or skills, nor of tools to build something anew: "the country so very pleasant, being always clothed with green, and full of pleasant fruits, and a variety of birds, ever warm, and never colder than in England in September. So that this place (had it the culture, that skillful people might bestow on it) would prove a Paradise" (Neville 67).

The abundance of food, the agreeable climate, the absence of dangerous animals or other inimical presence, all these factors concurred to ensure their survival for as long as they lived:

We found on Land a sort of fowl about the bigness of a Swan, very heavie and
fat, that by reason of their weight could not fly, of these we found little difficulty
to kill, so that was our present food; we carried out of England certain Hens and
Cocks to eat by the way; some of these when the ship was broken, by some means
got to land, \& bred exceedingly, so that in the future they were a great help unto
us; we found also a little River, in the flags, store of eggs, of a sort of foul much
like our Ducks, which were very good meat, so that we wanted nothing to keep
us alive. (Neville 66)

The restful, uneventful life with its abundance of food and absence of threat of human, animal, or atmospheric origin eradicated for the islanders notions of effort and commitment to improve themselves, both individually and as a community. A dolce far niente settled in, ingrained with the quite popular notion of "the land of Cockaigne," a wide-spread medieval parody of a vision of bliss, albeit of an epicurean nature, as it appears, for instance, in the thirteenth century Old French poem Le Fabliau de Cocagne. The poem consisted of a letter written by the Bohemian notary Henricus de Irsenia to the abbess of Cockaigne about a land of milk and honey where no harmful creature could exist, where there was a river full of jewels that descended from paradise, and a fountain of youth, and sensual nuns swimming naked in a stream (Encyclopaedia Britannica, "The Land of Cockaigne"). With small variations, the theme reappeared in the Kildare's Poems in the fourteenth-century, and a century later a Dutch rhyme called Het Luilekkerland [the lazy-luscious-land] described the land of Cockaigne as a mythical place where, in addition to abundance, there is no need to work. Several painters also depicted the land of Cockaigne, the most famous depiction being the 1567 piece by Bruegel the Elder. It is also the focus of the drinking songs In Taberna Quando Sumus "Ego sum abbas Cucaniensis" ("I am the Abbot of Cockaigne") in Carmina Burana, a collection of 254 songs recorded in Benediktbeuern, a thirteenth-century manuscript better known for its inclusion in Carl Orff's secular cantata composed in 1935. This dream of a way of living based 
on leisure, laziness, and the satiety of the senses has never faded away and, perhaps, the Puritan exacerbation of austerity induced the awakening of such dreams.

In The Isle of Pines there is abundance of food, although no alcoholic beverages are available, and jewelry is not appreciated. The climate is mild and, after a while, the behavioral rules deemed necessary in polite, civilised society vanish. According to empirical theories developed during the seventeenth and especially the eighteenth centuries, in addition to their internal, moral set of rules, people were also influenced by external factors, the most important of which was climate -as Montesquieu explained in his essay L'Esprit des Lois [The Spirit of the Laws] (1748)a concept that included "various characteristics of local environments (ranging from meteorological factors, such as the amount of sunshine or heat, to the landscape, and other geographical features) that were said to shape social practices, psychological dispositions, and even political institutions" (Muthu 37). Therefore, the small group of settlers somehow illustrates these theories insofar as they adapted themselves to their new environment and embraced a more natural way of living answering only to their basic appetites or passions (as Hobbes calls them in his Leviathan), and polygamy was adopted thus discarding Christian notions such as chastity. As George Pine was the only surviving male, monogamy did not seem relevant to happiness. The adoption of this new system happened gradually, without any evident moral qualms, yet following a kind of logic. At first, he was still attentive to considerations of rank and station, then he respected the more natural criterion of age, and finally he yielded to the then well-rooted racial prejudice:

Idleness and Fullness of everything begot in me a desire of enjoying the women, beginning now to grow more familiar. I had perswaded the two Maids to let me lie with them, which I did at first in private, but after, custome taking away shame (there being none but us) we did it more openly, as our Lusts gave us Liberty; afterwards my Master's Daughter was content also to do as we did; [...] one Night, I being asleep, my Negro (with the consent of the others) got close to me, thinking it being dark, to beguile me, but I awaking and feeling her, and perceiving who it was, yet willing to try the difference, satisfied my self with her, as well as with one of the rest: (Neville 67)

The thin veil of modesty is soon discarded, and the willingness of George Pine's female partners is lightly hinted at when mentioning the English women and more bluntly exposed when referring to the slave. This account twists the current gender ideology which still defended the need to control women's lustful appetites while confirming their inferior social and intellectual abilities by their passive role in reproduction (Kent 5-6). However, in other aspects George Pine fully complies with contemporaneous views on gender: he acts as the patriarch of his small community by organising his polygamous relationships so that his wives become pregnant in turn in order to take care of one another, and he discriminates against the Negro slave.

According to Sarah M.S. Pearsall, "beliefs about gender shaped the nature of English colonisation and indeed the British Atlantic world itself" (133). Therefore, replicating the metropolitan patriarchal order would ensure the political order of the newly-founded communities. Moreover, Englishmen claimed a moral superiority 
in relation to other settlers - such as Spaniards or Portuguese people of Catholic faith-and stayed away from native women so that they would not jeopardise social and colonial stability. The classification of individuals either by gender, class, or race, or a combination of two or even three of these factors, had a clear impact on each person's identity and power. Women's identity was traditionally associated with their reproductive function, framed either by the Galenic notion of the female reproduction organs as the inverse -and, therefore, inferior to men's- or by a later theory that considered female reproductive organs as distinct from the male's. In this case, the female body was just a passive vessel to receive the male's vital fluids (Pearsall 147-148). Nonetheless, above all, during the colonisation period class and race played an important role in social structure definitions. George Pine challenged metropolitan mores by having a relationship with his former master's daughter, who outranked him, and with an African slave, an inferior being according to the then current mentality.

Exploitation and inferior status existed long before the Atlantic momentum, but the Spanish and Portuguese maritime merchants were the first to use African and Indian slaves for hard labour. Englishmen followed suit. In the early stages of the modern empires, racial discrimination stemmed from the logic of economics and profit, and from the symbolic assertion on the part of settlers/conquerors of their superior status in relation to the native peoples they met in the far-away regions they occupied. The easiest way to discriminate was by attributing intellectual and moral meaning to different physical features such as colour, types of hair, or strength. In this light, African people were considered physically strong, able to do hard work, although intellectually and morally inferior to Europeans. Joyce E. Chaplin acknowledges that humankind has always established distinct levels of power and status based on several factors according to the mentality of the epoch: religion, language, custom, and political identity. However, there have been two essentially different types of discrimination, one before and the other after the rise of the modern empires (Chaplin 173-187). During the Middle Ages, the focus of discrimination was on religion -being or not being a Christian. This was a reversible condition; people could be converted and become part of Christendom. The more recent source of discrimination was irreversible because it resulted from inherited features. This type was a work in progress among seventeenth- and eighteenthcenturies scientists. Harvey's reproductive theory, for example, justified lineage in his final work Exercitationes de Generatione Animalium [Exercises on the Generation of Animals] (1651). Later on, Linnaeus added to the issue with his taxonomy system and the introduction of the concepts of genus and species. These theories circulated among philosophers and scientists, a small number of educated men, but the basic ideas were disseminated in newspaper articles and talked about in coffee shops. Even pseudo-scientists like Edward Long were seen as reliable sources. This wide acceptance is easily understandable: the scientific explanations justified discrimination and violence, making the double-standard morality inevitable in a universe inhabited by such a variety of creatures, some of them apparently in need of guidance and strict control. 
During the lifetime of George Pine and his female companions, this insular community is devoid of the violent pattern frequently adopted by European settlers towards the native people with whom they had dealings. Therefore, they are able to live in a natural society without restrictive rules, rewards or punishments. However, the prejudice against the African woman -and metonymically against all the African people- is patent in the narrative, and is associated with aggressive, predatory conduct, believed to be quite common among the 'savages', that is, non-Christian and non-European individuals. This is illustrated by Captain Van Sloetten's military intervention to put an end to a violent conflict between two groups of members of the Pine family. Some well-known authors rejected these notions and abhorred the voyagers' change of conduct when out of their original societies. Montaigne plays with the meaning of 'sauvage' [savage] to criticise the European travelers:

Those people [Amerindians] are wild [sauvage], just as we call wild [sauvage] the fruits that Nature has produced by herself and in her normal course; whereas really it is those that we have changed artificially and led astray from the common order, that we should rather call wild [sauvage]. The former retain alive and vigorous their genuine, their most useful and natural, virtues and properties, which we have debased in the latter in adapting them to gratify our corrupted taste. (Montaigne 152)

Nevertheless, according to George Pine's Relation - a first-person account of his voyage and his settling on the island-conforming to the racial prejudice of the times, he divided his numerous offspring into four groups gathered and named after their matriarchal ancestry: the English, after Sarah English (the Master's daughter); the Sparks and the Trevors, after the maids Mary Sparks and Elizabeth Trevor; and the Phils from the Christian name of the slave, Philippa, who did not have a family name. The demographic shortage, which had apparently justified the polygamous arrangement adopted by the first settlers, had come to an end after many sons and daughters were born to the four women. George Pine planned the new generation's marriages pairing a member of a group with someone from another group, and allowing them to live freely scattered over the island. The prejudice is later illustrated by the episode involving Captain Van Sloetten and some of his men when they were preparing for departure. The king of the Pines, George's grandson, asked for their help to contain a rebellion of sorts which had started between two of the four existing groups, the Phils and the Trevors. However, the individual responsible for the outbreak of this riotous episode was none other than a Phils:

Henry Phil, the chief Ruler of the Tribe or Family of the Phils [...] had ravished the Wife of one of the principals of the Family of the Trevors; which act being made known, the Trevors assembled themselves all together to bring the offender to Justice. But he knowing his crime to be so great as extended to the loss of life: fought to defend that by force, which he had unlawfully committed, whereupon the whole Island was in a great hurly burly, they being too great Potent Factions, the bandying of which against each other, threatned a general ruin to the whole State. (Neville 72) 
These racially motivated incidents and the consequent loss of control of the Pines' community were aggravated by its enlarged population and its dispersal over different parts of the island which weakened the spatial and social cohesion among the islanders. In Laura Rolings' words, "Perhaps this spatial differentiation between the first generation of Pines and the subsequent generations parallels the differentiation between the controlled society of the first generation and the chaotic, repeatedly threatened society of Pine's offspring" (13). The rise of discord due to a malevolent agent also echoes the biblical episode of Eve's temptation by the serpent causing the expulsion of the primeval pair from paradise, a controlled locus. In the case of the island of Pines, the malevolent agent has no reptilian features, but he is physically distinct from the others. The perpetrator, John Phil, who raped and attacked several inhabitants until he was put to death, was the second son of Philippa. In the next generation similar acts were perpetrated by Henry Phil. The discordant note led George's son and successor as king of the island to write a constitutional document reintroducing Christian faith and moral doctrine, as well as a penal code that included the death penalty for crimes against God -i.e. blasphemy- and crimes against society, such as rape and adultery. It also established penalties in cases of violent behavior towards other islanders. George's son also organized the governing of the island delegating powers to representatives of the several branches of the Pine family. Van Sloetten's narration thus confirms the relationship between individual moral codes of conduct and social stability, especially in distant places where political leadership is not efficient. The flippant rejection of Christian -specifically Puritandoctrine and ethics at the first stage of the colony caused transitory episodes of disruption potentially disintegrating the social structure, even a rather loose one, as was the case. In consequence, it questions the eutopian-or Morean- model of a happy, benevolent society where private and public interest converge. However, Morton, in The English Utopia (1952) considers the possible ambiguity of utopia and points to a clearer distinction between eutopia and dystopia: "For utopia is really the island which people thought or hoped or sometimes feared that the Britain of their day might presently become" (9).

Henry Neville, a subdued republican at the time of writing his utopian novel, had shared Harrington's and Merton's views about the fairer way to structure society and distribute wealth among its members. ${ }^{3}$ His mistrust of, and objections to, Cromwell's proclivity for authoritarian rule made him persona non grata and, from 1654 to 1658, he was banished from London. Perhaps the Arcadian influence of Harrington's Oceana (1656) made him envisage a well-ordered society ruled by a charismatic figure, like George Pine and his "royal" successors, though balanced by the division of actual executive power and a strict penal code. On the other hand,

${ }^{3}$ He explored this subject in his Plato Redivivus, or a Dialogue concerning Government (1681; reprinted under the title Discourses concerning Government, 1698), an un-Platonic dialogue developing a scheme for the exercise of the royal prerogative through councils of state responsible to parliament, and of which a third part should retire every year. This work was much admired by Hobbes. 
Neville's abhorrence of the Puritan zeal during the Cromwellian regime together with his penchant for satire-already evident in his parody The Parliament of Ladies (1647) - explain the polygamous relationship of the first settlers, thus defying domestic gender ideology and its impact on the imperial model of power between the metropolis and the colonies.

In Society under Siege (2002), Bauman considers utopia "a vision of a predesigned world, a world in which prediction and planning stave off the play of chance" (230), but Neville's narrator seems to contradict this notion attributing the changes to chance, climate, geography, and external elements in general. This approach was defended by several seventeenth- and eighteenth-century thinkers and explorers as factors responsible for the whims of human nature and their impact on the development of any society. Therefore, utopias situated in far-distant regions with external conditions distinct from the European scenario would allow for their particular conduct, sometimes exhibiting a dystopian facet ingrained in any imagined paradise from the point of view of European readers. As far as creativity is concerned, minor creators of fictional works -in the Tolkien sense of the term ${ }^{4}-$ are imperfect human beings. Ergo, their creations may be tinged by imperfection. Even More's Utopia admits the existence of "rotten apples" in its bosom, individuals who transgress and have to become slaves as punishment for their wrongdoings (More 83).

Their enormous physical distance from the explored mapped lands, and further emphasized by locating the site of good life on a far-away island or at the far end of a yet undiscovered and untrodden, testing and treacherous, sometimes downright impassable track. The trials and tribulation the lonely travelers suffered before reaching or accidently straying into the land of Utopia signaled the lack of obvious, let alone easy, passages from the world of everyday life to the world of 'good life' the newly discovered land incarnated. And whatever happiness could be relished within the territorial confines of Utopia could not be exported beyond its borders. (Bauman 223)

This insular social experiment that had taken place on the island for 98 years proves Bauman's reasoning: Pine's offspring never asked the Dutch captain to take them back to England; their home is there, in that island away from the established maritime trade routes. They kept the English language as their means of communication, and somehow they recovered their Christian faith. Their way of living is still characterized by the absence both of private property and the need for labour; the otium prevalent in that society did not meet its classical goal of spiritual, intellectual exercise free from everyday business, as Cicero uses it in De Oratore, ${ }^{5}$ just an everlasting leisure, contrary to the Protestant and Calvinist emphasis on work: "the common human obligation to labour in the garden of the Lord, in whatever manner is commensurate with one's God-given gifts and abilities on the one hand

\footnotetext{
4 Tolkien, On Fairy-Stories, 1939.

5 Cf. Andrew Lintott, "The Search for Otium," 215-53.
} 
and the needs of the situation on the other" (McGrath 225). The narrator comments precisely on the advantages labour could bring to the Pines: with the island's natural resources, if they chose to dedicate themselves to farming they could exceed many European countries praised for their wealth (Neville 75). Moreover, the epicurean emphasis on physical, ephemeral pleasures points to later examples of dystopia such as Huxley's Brave New World (1932) which focused on consumerism and transient sexual relationships by an alienated and manipulated population -an ersatz version of happiness.

The negative elements in The Isle of Pines may be viewed as the avantgarde dystopic nature of Neville's fiction, but they are balanced against a feeling of contentedness similar to the Aristotelian notion of aurea mediocritas. George Pine lived a contented life and died with a clear conscience; and the second generation's adjustments aimed to ensure the reestablishment of peace, at least for a long while. The narrator is aware of the blissful atmosphere of their society in spite of the islanders' few possessions and limited entertainment: "[...] we may account them fortunate, in that possessing little, they enjoy all things, as being contented with what they have, wanting those allurements to mischief, which our European Countries are enriched with" (Neville 74-75).

In sum, Neville's work may be read as a kind of challenge to the forgers of new ideologies he knew in his lifetime. To these potential builders of alternative models of society he presents a scenario with the perfect natural environment just to prove how human presence tampers with such a paradise on earth. Therefore, it is possible that he created a paradoxical literary form between the optimism of eutopia and the gloomy visions of dystopia: an imperfect utopia.

Reviews sent to author: 21 July 2019

Revised paper accepted for publication: 12 August 2019 


\section{WORKS CITED}

Bacon, Francis. "New Atlantis." The Advancement of Learning and New Atlantis. Ed. Arthur Johnston. Clarendon, 1974. 213-247.

Bauman, Zygmunt. Society under Siege. Polity, 2002.

Bernier, François. "Nouvelle Division de la Terre par les Différents Espèces ou Races qui l'habitent." Journal des Sçavans 24 Apr. 1684. <https://archive.org/details/JournalDesScavans1684>. Accessed 22 May 2019.

Bloch, Ernst. The Principle of Hope. Trans. Neville Plaice, Stephen Plaice, Paul Knight. 3 vols. Blackwell, 1986.

Brito, Bernardo Gomes de. História Trágico-Maritima. Lacerda Editores, 1998.

Chaplin, Joyce E. "Race." The British Atlantic World, 1500-1800. Ed. David Armitage and Michael Braddick. Palgrave MacMillan, 2009. 173-190.

Child, Josiah. Brief Observations Concerning Trade and the Interest of Money (1668). <https:// openlibrary.org/books/OL15412553M/Brief_observations_concerning_trade_and_ interest_of_money_by_J.C>. Accessed 12 Mar. 2018.

Child, Josiah. A New Discourse of Trade $(1668,1690) .<$ https://archive.org/details/anewdiscoursetr00chilgoog/page/n9>. Accessed: 20 Mar. 2018.

Defoe, Daniel. Robinson Crusoe. Penguin, 1987.

Erasmus, Desiderius. The Praise of Folly. Intr. A.H.T. Levi. Trans. Betty Radice. Notes by A.H.T. Levi. Penguin Classics, 1994.

Ford, Worthington Chauncey. The Isles of Pines by Henry Neville. An Essay in Bibliography. The Club of Odd Volumes, 1920. <http://www.gutenberg.org/files/21410/21410-h/21410-h. htm>. Accessed 14 Sep. 2018.

Grotius, Hugo. Mare Liberum [1609]. CreateSpace Independent Publishing Platform, 2012.

Harrington, James. The Commonwealth of Oceana [1656]. <http://www.gutenberg.org/files/2801 /2801-h/2801-h.htm>. Accessed 2 Oct. 2017.

Hobbes, Thomas. De Cive. 1642. <http://www.nlnrac.org/earlymodern/hobbes/documents/de-cive>. Accessed 20 May 2019.

Hobbes, Thomas. Leviathan. Dent, 1979.

Huxley, Aldous. Brave New World. Intr. Daniel Bradshaw. Vintage, 2004.

Kent, Susan Kingsley. Gender and Power in Britain, 1640-1990. Routledge, 1999.

LaHaye, Laura. "Mercantilism." The Concise Encyclopedia of Economics. Ed. David R. Henderson. Liberty Fund, 2008. <http://www.econlib.org/library/Enc1/Mercantilism.html\#>. Accessed 2 May 2019.

Levitas, Ruth. The Concept of Utopia. 1990. Peter Lang, 2010.

Lintott, Andrew. "The Search for Otium." Cicero as Evidence: A Historian's Companion. Oxford UP, 2008. 215-253.

Long, Edward. The History of Jamaica or, General Survey of the Antient and Modern State of the Island: with Reflections on its Situation Settlements, Inhabitants, Climate, Products, Commerce, Laws, and Government. T. Lownudes, 1774. <https://archive.org/details/ historyjamaicao01longgoog/>. Accessed 22 May 2019. 
MacGrath, Allister E. Reformation Thought. An Introduction. Blackwell, 1997.

Montaigne, Michel de. The Complete Essays of Montaigne. Ed. and trans. Donald Frame. Stanford UP, 1958.

Montesquieu, Charles Louis de Secondat, Baron de. “L'Esprit des Lois.” The Complete Works of M. de Montesquieu. Vol. 1. T. Evans, 1777. 4 vols. <https://oll.libertyfund.org/titles/montesquieucomplete-works-vol-1-the-spirit-of-laws>. Accessed 12 May 2019.

More, Thomas. Utopia. Ed. George M. Logan and Robert M. Adams. Cambridge UP, 1989.

Morton, A.L. The English Utopia. Lawrence \& Wishart, 1952.

Müller-Wille, Staffan. "Carolus Linnaeus Swedish botanist.” <https://www.britannica.com/ biography/Carolus-Linnaeus>. Accessed: 11 May 2019.

Mun, Thomas. "A Discourse of Trade from England into the East Indies." 1621. Ed. John Ramsay McCulloch. A Select Collection of Early English Tracts on Commerce from the Originals of Mun, Roberts, North, and Others, 1856. <https://oll.libertyfund.org/titles/mcculloch-aselect-collection-of-early-english-tracts-on-commerce-1856>. Accessed: 12 May 2019.

Mun, Thomas. England's treasure by forraign trade. 1664. MacMillan, 1895. <https://archive.org/ details/englandstre00muntuoft/page/n6>. Accessed 12 May 2019.

Muthu, Sankar. Enlightenment against Empire. Princeton UP, 2003.

Neville, Henry. The Isle of Pines Or, A late Discovery of a fourth ISLAND in Terra Australis, Incognita, 1668. An Essay in Bibliography by Worthington Chauncey Ford. The Club of Odd Volumes, 1920. Web <http://www.gutenberg.org/files/21410/21410-h/21410-h.htm>. Accessed: September 14, 2018.

Neville, Henry. The Parlament Of Ladies. Or Divers Remarkable Orders, Of The Ladies, At Spring Garden, In Parlament Assembled. Together With Certain Votes, Of The Unlawful Assembly, At Kate's, In Covent Garden. Both Sent Abroad To Prevent Misinformation. 1647. T. Cadell, 1768. <https://babel.hathitrust.org/cgi/pt?id=dul1.ark:/13960/t3708st9f\&view=1up\&seq>. Accessed 22 May 2019.

Neville, Henry. Plato Redivivus, Or, A Dialogue Concerning Government Wherein, By Observations Drawn From Other Kingdoms And States Both Ancient And Modern, An Endeavour Is Used To Discover The Present Politick Distemper OfOur Own, With The Causes And Remedies [...]. S.I., 1681. <https:/quod.lib.umich.edu/cgi/t/text/text-idx?c=eebo;idno=A52855.0001.001>. Accessed 22 May 2019.

OrfF, Carl. "Ego Sum Abbas.” In Taberna. Carmina Burana, 1936.

Pearsall, Sarah M.S. "Gender." The British Atlantic World, 1500-1800. Ed. David Armitage and Michael Braddick. Palgrave MacMillan, 2009. 133-151.

Pinto, Fernão Mendes. Peregrinação [1614] e Outras Obras. 4 vols. Sá da Costa Editora, 1984.

Pohl, Nicole. "Utopianism after More: the Renaissance and Enlightenment." The Cambridge Companion to Utopian Literature. Ed. Gregory Claeys. Cambridge UP, 2010. 51-78.

Purchas, Samuel. Hakluytus Posthumus or Purchas his Pilgrimes; Contayning a History of the World, in Sea Voyages and Lande Travells, by Englishmen and Others. 1625. Vol. 1. Macmillan, 1905. 20 vols. <https://archive.org/stream/hakluytusposthum01purcuoft/ hakluytusposthum01purcuoft_djvu.txt>. Accessed 11 Feb. 2018.

Roling, Laura. Henry Neville's The Isle of Pines: A Peculiar Utopia. MA Diss. U Amsterdam, 2014.

SAID, Edward. Orientalism. Penguin, 2003. 
Scheckter, John. The Isle of Pines, 1668: Henry Neville's Uncertain Utopia. Ashgate, 2011.

Sмiтh, Adam. An Inquiry into the Nature and Causes of the Wealth of Nations. 1776] Web <https:// www.econlib.org/library/Smith/smWN.html?chapter_num=1\#book-reader $>$. Accessed 10 May 2019.

Swift, Jonathan. Gulliver's Travels. Dover Publications. Unabridged edition, 1996.

The Land of Cockaigne. Encyclopaedia Britannica. <https://www.britannica.com/topic/Cockaigne>. Accessed 2 Oct. 2018.

The Land of Cockaigne: A Utopian World on Earth Full of Meal and Pleasures. <https://arthive.com/ publications/2535-The_Land_of_Cockaigne_a_utopian_world_on_earth_full_of_meal_ and_pleasures>. Accessed 21 May 2019.

Tolkien, J.R.R. On Fairy Stories. Ed. Verlyn Flieger. Harper Collins, 2014.

Webster, C. "Harvey's De Generatione: Its Origins and Relevance to the Theory of Circulation." The British Journal for the History of Science 3.3 (1967): 262-274. <https://www.cambridge. org/core/journals/british-journal-for-the-history-of-science/article/harveys-de-generationeits-origins-and-relevance-to-the-theory-of-circulation/02D6A7C84FE39C08E2F6D2529 B66F7C4>. Accessed 20 May 2019.

Vieira, Fátima. "The Concept of Utopia." The Cambridge Companion to Utopian Literature. Ed. Gregory Claeys. Cambridge UP, 2010. 3-27. 
